\title{
The Edaphic-Endemics in the Metal-Rich Soils of Mt. Kiamo in Malaybalay, Bukidnon, Philippines
}

\author{
LOWELL G. ARIBAL \\ ORCID No. 0000-0002-8530-3267 \\ ariballowell@gmail.com \\ College of Forestry and Environmental Science, \\ Central Mindanao University, Musuan, \\ Bukidnon, Philippines \\ JESSIE CRIS D. POROT \\ ORCID No. 0000-0002-3883-1454 \\ porot.jd@gmail.com \\ College of Forestry and Environmental Science, \\ Central Mindanao University, Musuan, \\ Bukidnon, Philippines \\ JOSEPH A. PAQUIT \\ ORCID No. 0000-0001-7566-6227 \\ jcpaquit@cmu.edu.ph \\ College of Forestry and Environmental Science, \\ Central Mindanao University, Musuan, \\ Bukidnon, Philippines \\ MYRNA G. PABIONA \\ ORCID No. 0000-0002-8619-0436 \\ myrnagpabiona@gmail.com. \\ Department of Soil Science, College of Agriculture, \\ Central Mindanao University, Musuan, Maramag, \\ Bukidnon, Philippines
}




\begin{abstract}
Serpentine soils also known as ultramafic soils comprise 5 percent of the total land area of the Philippines. Majority of the ultramafic soils occur at the edges of the mainland and small island groups. However, little information had been known regarding inland ultramafic forest ecosystems just like Mt. Kiamo, which form part of the northern Mindanao ultramafic soils. Nine sampling plots with 20x20m dimensions were established within the lower, middle and top elevations at 1,563 to 1,782 masl. All plants having $\geq 5 \mathrm{~cm}$ dbh were identified and recorded. Soil characterization was done by digging a $1 \times 1 \mathrm{~m}$ hole at variable depths within sampling plots. Composite soil samples were collected on every horizon and analyzed. Result showed that Mt. Kiamo is composed of 151 species belonging to 114 families and 129 genera. The dominant species include Symplocos ophirensis, Myristica sp., Polyosma integrifolia Blume, Calophyllum soulattri, Phyllanthus everettii, Madhuca sp., Scaevola micrantha, Ardisia elliptica, Weinmannia urdanetensis, Morella javanica, and Omalanthus fastuosus. Soil analysis revealed an extremely high level of $\mathrm{Ni}, \mathrm{Cr}, \mathrm{Mn}$ and Fe. Canonical Correspondence Analysis showed that species' dominance, frequency, and diversity was influenced by $\mathrm{Ni}$, soil moisture and thickness while plant density was influenced by $\mathrm{Cr}$ and bulk density.
\end{abstract}

Keywords: Mt. Kiamo, ultramafic, serpentine, Bukidnon

\title{
INTRODUCTION
}

Since soil is the growing medium of the majority of all plants, the thought that soil exerts immediate control in dictating the vegetation composition, distribution, occurrences, and diversity is the readily acceptable rationale. However, because plants gradually alter the soils in which they grow, it is ambiguous and quite difficult to conclude whether the plants prefer the soil type or the soil creates them (Blinkey 1995). Further, there are clear mechanisms by which dominant plants can alter the properties of soils beneath their crowns (Gesper and Holowaychuk 1970; Crozier and Boerner 1986; Boerner and Kolowsky 1989). Due to this complexity, there is an abundance of literature reflecting varied concepts on species assemblage, richness, and distribution. 
For instance, according to Archibald (1995), it was De Candolle, who in 1874 stated that heat requirements and drought tolerance influenced the vegetation distribution. Engelbrecht et al. (2007) suggest that niche differentiation on soil water availability is a direct determinant of both local- and regional-scale distributions of tropical trees. There is a strong correlation between climate and distributional patterns of both individual plant species (Austin et al. 1990, Leathwick and Mitchell 1992, Lenihan 1993, Zhang 1998) and communities (Walter 1979, Zhang 1987, Prentice et al. 1992) over a wide range of spatial scales. Large changes in the composition and distribution of vegetation from regional to global scales will occur if climates change as predicted (Leathwick 1995, Zhang et al. 1997). Topographic features associated with differential drainage regimes and soil properties have been found to be strongly correlated with species distribution on a local scale (Bourgeron 1983; Johnston 1992). Richardson et al. (1995) concluded that topographic and soil variability may be an explanation for the patterns of coexistence between species richness and environmental gradients. Pausas and Austin (2001) suggested that studying the multidimensional gradients of resource, and environmental parameters are the key element to understanding plant species richness. John et al. (2006) stressed that soil nutrients influence spatial distributions of tropical tree species and that there is ample evidence to support that species distributions are determined by soils and habitat factors at the landscape and regional scales whereas belowground resource availability plays an important role in the assembly of tropical tree communities at local scales.

Amidst the wealth and variety of generalizations, we intend to describe in this paper the soil and vegetations of Mt. Kiamo, which is an inland ultramafic mountain forest ecosystem. Ultramafic soils, also known as serpentine soils comprise 5 percent of the total land area of the Philippines. Ultramafic soils have high concentrations of heavy metals such as magnesium $(\mathrm{Mg})$, iron $(\mathrm{Fe})$, chromium $(\mathrm{Cr})$, cobalt $(\mathrm{Co})$, and nickel $(\mathrm{Ni})$, and low concentrations of phosphorus (P), potassium (K), and calcium (Ca) (Proctor 2003). The low concentrations of the soil macroelements coupled with extremely high levels of heavy metals have led many ecologists to believe that this ecosystem could not support vegetation. However, studies have shown that there were specific species distributions of vegetation in the serpentine soils (Proctor et al. 1999). Thus, we present in here the species composition of an ultramafic soil in which through phenotypic tolerances and adaptive mechanisms have enable these species to survive despite the extremely inhospitable condition. 


\section{OBJECTIVES OF THE STUDY}

The study aimed to: 1) characterize the soil physico-chemical properties and floral resources of Mt. Kiamo; and 2) further infer patterns of species endemism and occurrences in an inland serpentine ecosystem.

\section{MATERIALS AND METHODS}

\section{Locale of the Study}

The study was conducted in Mt. Kiamo, Barangay Kibalabag, Malaybaly City, Bukidnon with geographic coordinates of $8^{\circ} 15^{\prime} 340^{\prime \prime} \mathrm{N}$ and $125^{\circ} 08^{\prime} 903^{\prime \prime}$ (Figure 1). Mount Kiamo form part of the ultramafic areas in northern Mindanao (Fernando et al. 2008). The climate classification falls under Type IV or intermediate $\mathrm{B}$ type, which is characterized by the absence of a pronounced maximum period and dry season. May to October is where heavy rains occur, and rain falls at a yearly average of $2,800 \mathrm{~mm}$ and occurs throughout the year. Mt. Kiamo is consisted of forested areas and a vast marginal land. The marginal land is an abandoned kaingin area occurring at elevations 1,193 to 1,300 masl. The forested landscape occurred at elevations 1,400 to 1,790 masl. Establishment of sampling plots and actual data gathering was done on November 2014 to January 2015 at the onset of the dry months.

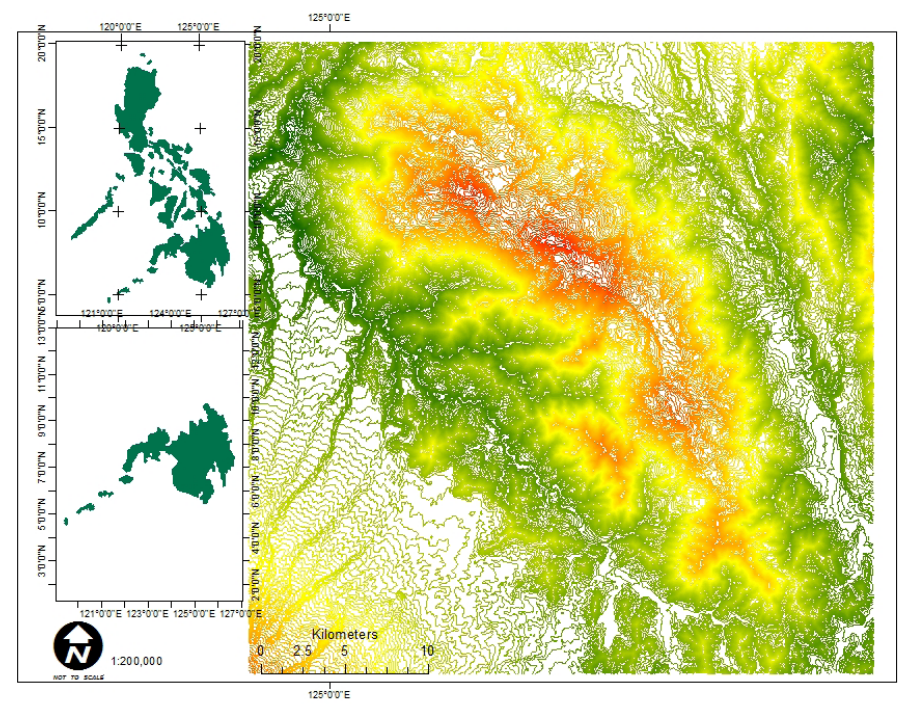

Figure 1. Topographic map of the study site. 


\section{Establishment of Sampling Plots}

Three $20 \times 20 \mathrm{~m}$ plots spaced 50 meters apart were established on the lower, mid and top elevations to sample the whole forest ecosystems of Mt. Kiamo. Plots at lower elevations were established at 1563-1570 masl, mid-elevation at 1571-1580 masl and top elevations were at 1675-1782 masl. The distances and locations of every plot were pre-determined using Google satellite image as well as using topographic maps.

\section{Sampling of Vascular Plants}

All tree species with $\geq 2 \mathrm{~cm}$ at diameter breast height $(\mathrm{DBH})$ within the sampling plots were identified and recorded. Sample specimens were collected for further identification and to serve as a reference in the future. Identification of species was done with the aid of taxonomic keys and literatures from floras of Rojo, J.P. (1999); Fernando et al. (2004) and (2008); Co et al. (2006); Pancho \& Gruezo (2006); LaFrankie (2010); and van Balgooy (1997). These samples were deposited in the College of Forestry and Environmental Science Herbarium.

\section{Soil Analyses}

Soil physicochemical properties such as $\mathrm{pH}$, bulk density, organic matter content and moisture content were analyzed at the Soil and Plant Analysis Laboratory (SPAL) of Central Mindanao University. For heavy metal content determination, some samples were sent to the National Institute of Molecular Biology and Biotechnology at the University of the Philippines Los Baños, Laguna for analyzes via X-ray Flourescence and Atomic Absorption Spectophotometry (AAS).

\section{Quantitative Vegetation Analysis}

The variables for measuring the magnitude of species diversity and species importance value (SIV) was used which includes: species density, dominance, and frequency. Species with the highest importance value were considered as the most dominant species. The Mueller-Dombois formula was used in the determination of SIV.

\section{RESULTS AND DISCUSSION}

\section{Species Composition}

A. Lower Elevation Zone (1563 - 1570 masl)

Within the three (3) plots established, at least 31 species were recorded. The 
following species includes, namely: Symplocos ophirensis, Myristica sp., Polyosma integrifolia, Calophyllum soulattri, Phyllanthus everettii, Scaevola micrantha, Falcatifolium gruezoi, Madhuca sp., Syzygium sp., Podocarpus rumphii, Agathis philippinensis, Kibatalia sp., Ascarina philippinensis, Garcinia sp., Elaeocarpus merrittii, Litsea sp., Discocalyx mindanaensis, Turpinia ovalifolia, Eurya coriacea, Elaeocarpus argenteus, Vaccinium sp. Prunus grisea, Helicia robusta, Dacrycarpus imbricatus, Gordonia luzonica, Microtropis curranii, Gymnostoma sumatranum, Palaquium sp. and Trichospermum involucratum. The top five (5) most dominant species based on SIV were Symplocos ophirensis, Myristica sp., Polyosma integrifolia, Calophyllum soulattri and Phyllanthus everettii.

B. Middle Elevation (1570 - 1580 masl)

Twenty-five (25) species were recorded within the three (3) plots established. The species composed of Calophyllum soulattri, Agathis philippinensis, Madhuca sp., Scaevola micrantha, Ardisia elliptica, Polyosma integrifolia, Podocarpus rumphii, Osmoxylon simplicifolium, Falcatifolium gruezoi, Myrmeconauclea strigosa, Syzygium sp., Rauvolfia sumatrana, Garcinia sp., Elaeocarpus merrittii, Turpinia ovalifolia, Meliosma pinnata, Phyllocladus hypophyllus, Kibatalia sp., Eurya coriacea, Dacrycarpus imbricatus, Planchonella firma, Myristica sp., Syzygium vaccinifolium, Platea excelsa and Psychotria sp. Species with highest SIV includes Calophyllum soulattri, Agathis philippinensis, Madhuca sp., Scaevola micrantha and Ardisia elliptica.

\section{Top Elevation Zone (1675 - 1782 masl)}

Forty-three (43) trees were identified in the top elevation zone. The species includes: Weinmannia urdanetensis, Calophyllum soulattri, Morella javanica, Homalanthus populneus, Madhuca sp., Falcatifolium gruezoi, Ardisia elliptica, Leptospermum javanicum, Decaspermum sp., Medinilla sp., Myrsine mindanaensis, Melastoma malabathricum, Agathis philippinensis, Astronia sp., Phyllocladus hypophyllus, Phyllanthus everettii, Ascarina philippinensis, Podocarpus rumphii, Clethra canescens, Ardisia sp., Elaeocarpus argenteus, Kibatalia sp., Hydrangea scandens, Rauvolfia sumatrana, Vaccinium sp., Madhuca sp., Melicope triphylla, Leucosyke sp., Neolitsea villosa, Symplocos ophirensis, Eurya coriacea, Magnolia candollei, Myrmeconauclea strigosa, Trichospermum involucratum, Osmoxylon simplicifolium, Prunus grisea var. grisea, Radermachera coriacea, Scaevola micrantha, Schefflera multiramosa, Timonius sp., Turpinia ovalifolia, Vaccinium platyphyllum, and three (3) species of Nepenthes. Weinmannia urdanetensis, Calophyllum soulattri, Morella javanica, Homalanthus populneus and Madhuca sp. were the most dominant species based on SIV. 


\section{Heavy Metals}

Among the heavy metals and based on the order of magnitude, Fe showed an enormous amount ranging from $353,786.21 \mu \mathrm{g} / \mathrm{g}$ to $482,925.28 \mu \mathrm{g} / \mathrm{g}$ from the lower up to the topmost elevation followed by $\mathrm{Cr}, \mathrm{Mn}$, and $\mathrm{Ni}$ (Table 1).

Table 1. Heavy Metal Content $(\mu \mathrm{g} / \mathrm{g})$ in the Soil of Mt. Kiamo Using AAS

\begin{tabular}{lcccc}
\hline \hline Elevation & $\begin{array}{c}\text { Nickel } \\
(\mathrm{Ni})\end{array}$ & $\begin{array}{c}\text { Iron } \\
(\mathrm{Fe})\end{array}$ & $\begin{array}{c}\text { Manganese } \\
(\mathrm{Mn})\end{array}$ & $\begin{array}{c}\text { Chromium } \\
(\mathrm{Cr})\end{array}$ \\
\hline Top & $1,347.27$ & $353,786.21$ & $2,337.30$ & $6,060.19$ \\
Middle & $2,616.54$ & $585,155.08$ & $17,461.53$ & $5,041.82$ \\
Bottom & $1,248.29$ & $482,925.28$ & $7,924.13$ & $6,738.86$ \\
\hline \hline
\end{tabular}

\section{Correlation Analysis}

Pearson's correlation analysis was used to determine the relationship between the soil properties and variables of vegetation. Soil moisture content and chromium showed a negative correlation $(\mathrm{P}<0.05)$ implying that the soils of $\mathrm{Mt}$. Kiamo with low moisture content contain high concentrations of Chromium $(\mathrm{Cr})$ and vice versa.

\section{Canonical Correspondence Analysis}

Figure 2 shows the relationship of vegetation characteristics and soil properties. In quadrant 1 , species diversity has been influenced by nickel, soil moisture and soil thickness. In quadrant 2, species occurrence has been affected by soil $\mathrm{pH}, \mathrm{OM}$, and iron. In quadrant 3 , SIV and number of individuals have been affected by chromium and bulk density. The other points in quadrant 1 , relative frequency and relative dominance are somewhat affected by nickel, soil moisture and soil thickness. In quadrant 4 , mean density and mean height do not show a clear relationship with the soil properties. 


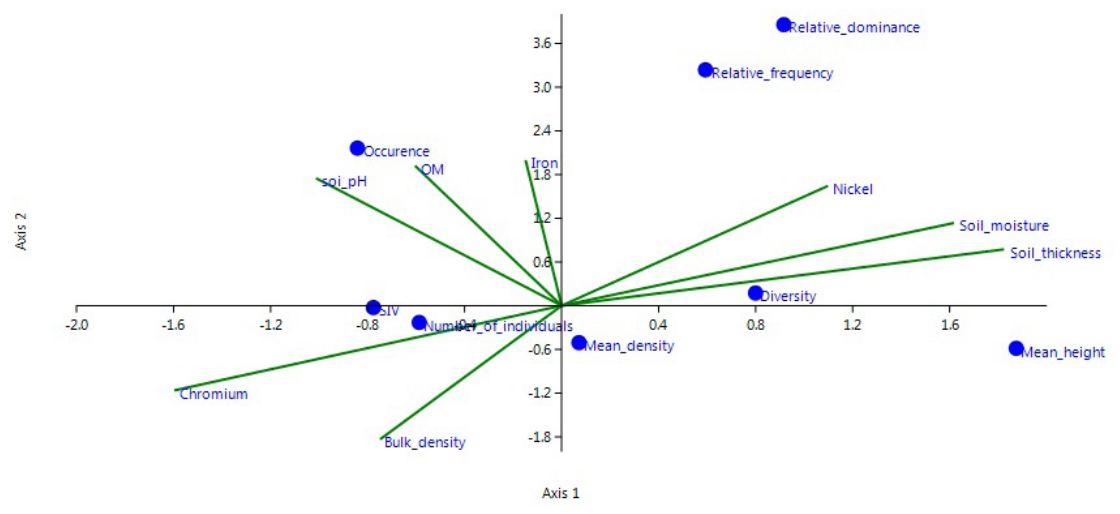

Figure 2. Canonical Correspondence Analysis.

\section{Species Composition}

There were of 725 individuals belonging to 40 families representing 77 genera were recorded from the ten sampling plots including the subplots established. These plots were established at elevations ranging from 1563-1782 masl. Based on the works of Fernando et al. (2008), the classification of the forest formation or forest type occurring on such elevation could be the "Tropical Lower Montane Rainforest" and species such as Shorea ploysperma is abundant and dominant along with various species of oaks while the tree genera and families that are better represented in this zone which includes: Agathis, Podocarpaceae (Dacrycarpus, Dacrydium, Podocarpus, Phyllocladus), Acer, Clethra, Fagaceae (Lithocarpus, Quercus), Litsea, Symplocos, and Syzygium. These species have also occurred in Mt. Kiamo, however, shows low dominance for the genus Clethra, Podocarpus, Phyllocladus, Acer, Symplocos and Syzygium while Shorea polysperma has never been recorded. According to Fernando et al. (2008) while Mt. Hamiguitan was also considered as ultramafic at higher elevations, however, at lower elevations the typical lowland evergreen and lower montane rain forests could be observed comprising of trees with crooked stems and branches. Moreover, the heavy metal indicator Scaevola micrantha and other trees such as Myrsine sp., Elaeocarpus sp., Alstonia sp., Weinmannia urdanetensis, Leptospermum javanicum, Decaspermum $s p$., and several species of Syzygium are the most dominant species. This scenario is well-depicted in Mt. Kiamo. 


\section{Soil Properties}

The heavy metals present in the soil confirm that the Mt. Kiamo is an ultramafic. Nickel $(\mathrm{Ni})$ has a mean concentration of $1,737.37 \mu \mathrm{g} / \mathrm{g}$ in which normal soil should only have a maximum of $75 \mu \mathrm{g} / \mathrm{g}$. On the other hand, Chromium $(\mathrm{Cr})$ has a mean concentration of 5,946.96 $\mu \mathrm{g} / \mathrm{g}$ more than the value of normal soils which should only have 3,000 $\mu \mathrm{g} / \mathrm{g}$ based on US-EPA (1993). However, in Mt. Kiamo the level of concentration of $\mathrm{Cr}$ is much higher in concentration the lower elevation, followed by the top and middle elevation but the nickel concentration is in descending order from the middle elevation, top, and lower elevation. For the other heavy metals, it can also be observed that the soils of Mt. Kiamo have a considerable amount of $\mathrm{Fe}$ and $\mathrm{Mn}$. The iron concentration in Mt. Kiamo is beyond the normal range. According to Vanmechelen et al. (1997), the typical range of iron concentrations in soils ranges from 100 to $100,000 \mu \mathrm{g} / \mathrm{g}$ whereas the

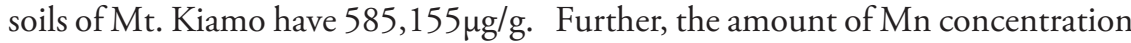
in Mt. Kiamo is beyond the levels on common soils. According to Schulte and Kelling (2004), Mn in common soils is about 3,000 $\mu \mathrm{g} / \mathrm{g}$ whereas Mt. Kiamo has an average concentration of $9,249 \mu \mathrm{g} / \mathrm{g}$.

\section{Species Distribution and Pedo-Botanical Association}

At elevations 1563-1570 masl the dominant species in Mt. Kiamo includes Symplocos ophirensis, Myristica sp., Polyosma integrifolia, Calophyllum soulattri and Phyllanthus everettii. At the middle elevations at elevations 1570-1580 masl, Calophyllum soulattri, Agathis philippinensis, Madhuca sp., Scaevola micrantha and Ardisia elliptica were the dominant species while in the top elevation (1675-1782 masl) is dominated with Weinmannia urdanetensis, Calophyllum soulattrri, Morella javanica, Homolanthus populneus, and Madhuca sp. The species distribution depicted in Mt. Kiamo is typical among the ultramafic soils in Mindanao at elevations $\geq 1000$ masl specifically for the species Scaevola micrantha and Falcatifolium gruezoi including several species of Syzygium (Myrtaceae) which is considered as true ultramafic species (Fernando et al. 2008; Amoroso \& Aspiras 2011; Salas 2014; pers. obs. in Mt. Tristan, Dinagat). In comparison with the ultramafic 'red mountains' in Carrascal in Surigao del Sur, Salas (2013) reported the dominance of the species Shorea negrosensis, Tristanopsis decorticata, Hopea foxworthyi, Shorea stylosa, and Planchonella sp. However, the species of Dipterocarps (i.e. Shorea, Hopea) including T. decorticate was never recorded in Mt. Kiamo probably because the sampling plots of Salas (2013) was located at elevations 400-650 masl. Further, Mt. Kiamo is continuously destroyed for agriculture purposes hence majority of the Dipterocarps may have been lost and were logged many years ago while $T$. decorticata occurs at Surigao-Leyte as the natural biogeographic region. 
Regarding the soil-plant association (pedo-botanical) although canonical correspondence analyzes (CCA) suggest that nickel, soil moisture and soil thickness influences the species diversity, relative dominance, and relative frequency while the number of individuals was influenced by chromium and bulk density however no definite pattern of association could be generalized. Also, the absence of the data in soil taxonomy particularly in the identification of soil classes could also deter the determination of this soil-plant association.

\section{CONCLUSIONS}

Comparing our results with other forest over ultramafic soils in Mindanao such as Mt. Hamiguitan in Davao Oriental, Red Mountains of Carrascal, Surigao Province and Mt. Tristan of Valencia, Dinagat Provinces, we therefore conclude that those common species observed on all sites particularly Scaevola micrantha, Falcatifolium gruezoi, Calophyllum soulattri, Agathis philippinensis, Madhuca sp. and Syzygium spp. are the true ultramafic species or the so-called "edaphic endemics" as emphasised by Bondada \& Ma (2003). We believed that other species observed which were common to tropical lower montane rainforest were the species that develops adaptation and tolerance to the extremely high levels of heavy metals in the soil that may kill other plant species, hence their survival.

\section{ACKNOWLEDGEMENTS}

The authors would like to thank the good people and Barangay Officials of Barangay Kibalabag, Malaybalay City for allowing us to conduct this study on their ancestral lands.

\section{LITERATURE CITED}

Amoroso VA, Aspiras R. 2010. Hamiguitan Range: A sanctuary for native flora. Saudi Journal of Biological Science, 18: 7-15.

Archibald OW. 1995. Ecology and World Vegetation. Vegetation and environment - introductory concepts. Springer Netherlands, 1-14.

Austin MP, Nicholls AO, Margules CR. 1990. Measurement of the realized qualitative niche: environmental niches of five Eucalyptus species. Ecology Monograph 60: 161-177. 
Blinkey D. 1995. The influence of tree species on forest soils-processes and patterns. In: D. Mead and G. Will (eds). Proceedings of the Trees and Soils Workshop, Lincoln University. Agronomy Society of New Zealand Special Publication 10. Lincoln University Press, Canterbury, New Zealand, $1-34$.

Boerner REJ, Kolowsky SD. 1989. Microsite variation in soil chemistry and nitrogen mineralization in a beech-maple forest. Soil Biology and Biochemistry 21: 795-801

Bourgeron PS. 1983. Spatial aspects of vegetation structure. In: Golley, F.B. (ed), Ecosystems of the world 14A -Tropical rain forest ecosystems, structure and function. Elsevier, Amsterdam, 29-47.

Co L, LaFrankie J, Lagunzad D, Pasion K, Consunji H, Bartolome N, Yap S, Molina J, Tongco M, Ferreras U, Davies S, Ashton P. 2006. Forest Trees of Palanan, Philippines: A Study in Population Ecology. Center for Integrative and Development Studies (CIDS), University of the Philippines - Diliman, Quezon City, Philippines, 313 pp.

Crozier CR, Boerner REJ. 1986. Stemflow induced soil nutrient heterogeneity in a mixed mesophytic forest. Bartonia 52:1-8.

Engelbrecht BMJ, Comita LS, Condit R, Kursur TA, Tyree MT, Turner BL, Hubbell SP. 2007. Drought sensitivity shape species distribution patterns in tropical forests. Nature 447: 80-83

Fernando ES, Sun BY, Suh MH, Kong HY, Koh KS. 2004. Flowering Plants and Ferns of Mt Makiling. ASEAN-Korea Environmental Cooperation Unit (AKECU). GeoBook Publishing Co., 368 pp.

Fernando ES, Suh MH, Lee J, Lee DK. 2008. Forest Formations of the Philippines. ASEAN-Korea Environmental Cooperation Unit (AKECU). GeoBook Publishing Co., 232 pp.

Gesper PL, Holowaychuk N. 1970. Effects of stemflow water on a Miami soil under a beech tree. I. Morphological a physical properties. Soil Science Society of America Proceedings 34: 779-786 
John R, Dalling J, Harms K, Yavitt J, Stallard R, Mirabello M, Hubbell S, Valencia R, Navarrete H, Vallejo M, Foster R. 2006. Soil Nutrients influence spatial distributions of tropical tree species. The National Academy of Sciences of the USA. Vol. 104 No. 3

Johnston MH. 1992.Soil-vegetation relationships in a tabonuco forest community in the Luquillo Mountains of Puerto Rico. Journal of Tropical Ecology 8: 253-263.

LaFrankie JV Jr. 2010. Trees of Tropical Asia: An Illustrated Guide to Diversity. Black Tree Publications, Inc. Philippines.750 pp.

Leathwick JR, Mitchell ND. 1992. Forest pattern, climate and volcanism in central North Island, New Zealand. Journal of Vegetation Science 3: 603-614.

Leathwick JR. 1995. Climatic relationships of some New Zealand forest tree species. Journal of Vegetation Science 6: 237-248

Lenihan JM. 1993. Ecological response surfaces for North American boreal tree species and their use in forest classification. Journal of Vegetation Science 4: 667-680.

Pancho JV, Gruezo WSM. 2006. Vascular Flora of Mount Makiling and Vicinity (Luzon: Philippines), Part 2. National Academy of Science and Technology (NAST) Philippines, Department of Science and Technology, Bicutan, Taguig City and Institute of Biological Sciences, College of Arts and Sciences, University of the Philippines Los Baños, College, Laguna, Philippines, 626 pp.

Pausas J, Austin M. 2001. Patterns of plant species richness in relation to different environments: An appraisal. Journal of Vegetation Science 12:153-166, IAVS; Opulus Press Uppsala. Printed in Sweden

Prentice IC, Cramer W, Harrison SP, Leemans R, Monserud RA, Solomon AM. 1992. A global model based on plant physiology and dominance, soil properties and climate. Journal of Biogeography 19: 117-134. 
Proctor, JL, Bruijnzeel A, Baker AJM. 1999. What Causes the Vegetation Types on Mount Bloomfield, a Coastal Tropical Mountain of the Western Philippines. Global Ecology and Biogeography 8: 347-354.

Proctor J. 2003. Vegetation and soil and plant chemistry on ultramafic rocks in the tropical Far East. Perspectives in Plant Ecology, Evolution and Systematics, 6, 105- 124 .

Richardson DM, Cowling RM, Lamont BB, van Hensbergen HJ. 1995. Coexistence of Banksia species in South-western Australia: The role of regional and local processes. Journal of Vegetation Science 6: 329-342.

Rojo JP. 2007. Revised Lexicon of Philippine Trees. Forest Products Research and Development Institute. Department of Science and Technology. College, Laguna, Philippines, 484.

Salas JB. 2013. Phytoremediation Potential of Trees Colonizing Nickel Mining Site in Carrascal, Surigao Del Sur. Unpublished Undergraduate Thesis. Central Mindanao University, Musuan, Bukidnon, 62 pp.

Schulte EE, Kelling KA. 2004. Soil calcium to magnesium ratios - Should you be concerned? A Bulletin G2986. University of Wisconsin Extension Service. Madison, Wisconsin, USA.

United States Environmental Protection Agency (US-EPA). 1993. National RCRA Hazardous Waste Biennial Report.

Van Balgooy MMJ. 1997.Malesian Seed Plants: An aid for identification of Families and Genera. Rijksherbarium/Hortus Botanicus, 154pp.

Vanmechelen L, Groenemens R, van Raust E. 1997. Forest soil condition in Europe. Results of a large scale soil survey, Technical report. EC, UN/ ECE, Ministry of the Flemich Community, Brusseles, Geneva, p. 259

Walter H. 1979. Vegetation of the earth and ecological systems of the geo-biosphere. Ed. 2. Springer-Verlag, New York.

Zhang JT. 1998 Canonical PCA and its application to vegetation-climate relations in Shanxi, North China. Acta Geographica Sinica 56: 256-263. 
Zhang JT. 1987. The main vegetation types and their rational utilization in Northwest Shanxi. Journal of Wuhan. Botanical Research 5: 373-382.

Zhang XS, Zhou GS, Gao Q, Ni J, Tang HP. 1997. Study of global change and terrestrial ecosystems in China. Earth Science Frontiers 4: 137-144 (in Chinese with English abstract). 

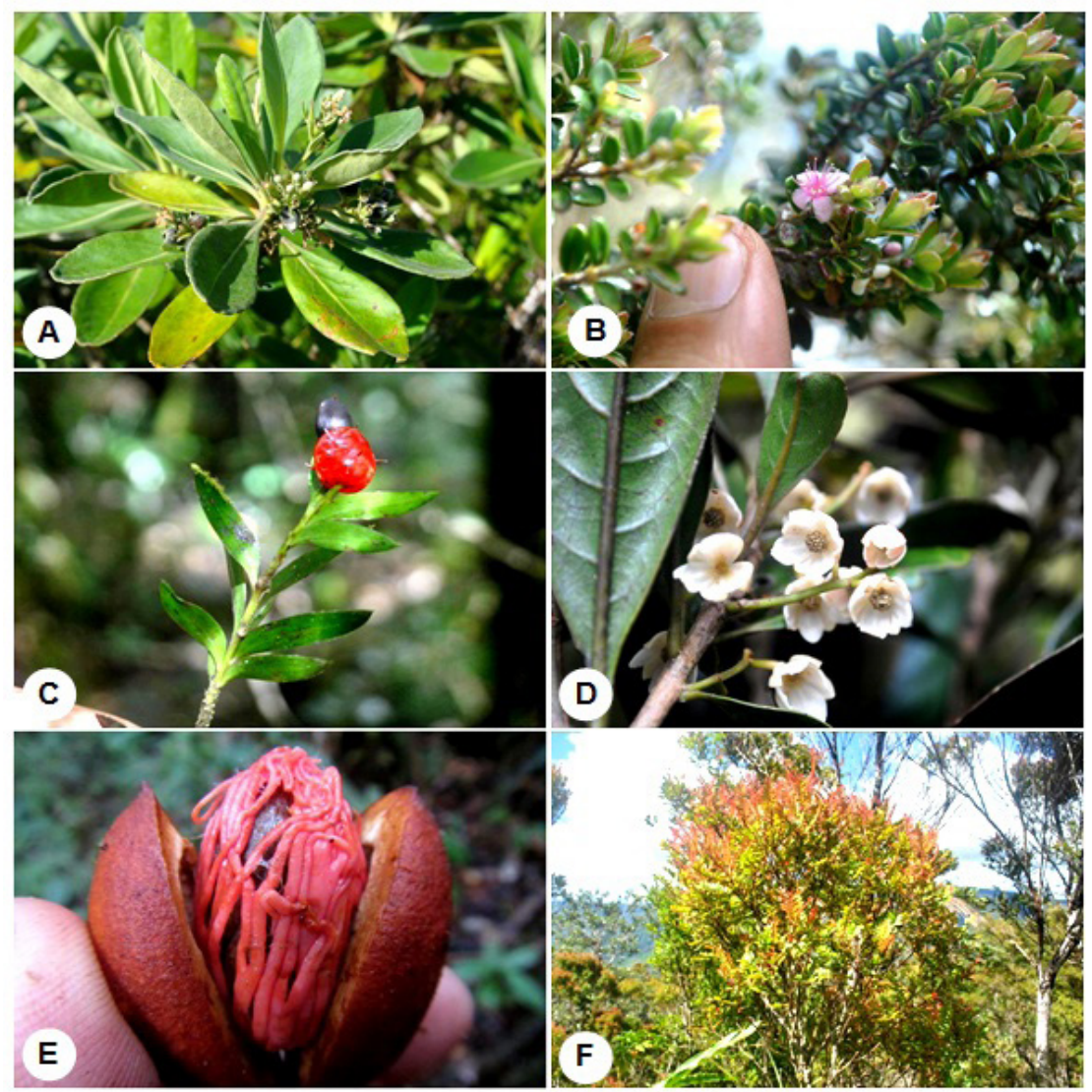

Plate 1. A. Scaevola micrantha C.Presl., B. Leptospermum javanicum Blume,

C. Falcatifolium gruezoi de Laub, D. Symplocos ophirensis C.B. Clarke, E. Myristica sp., F. Weinmannia urdatenensis Elmer. 
Asian Journal of Biodiversity Vol. 7 January 2016

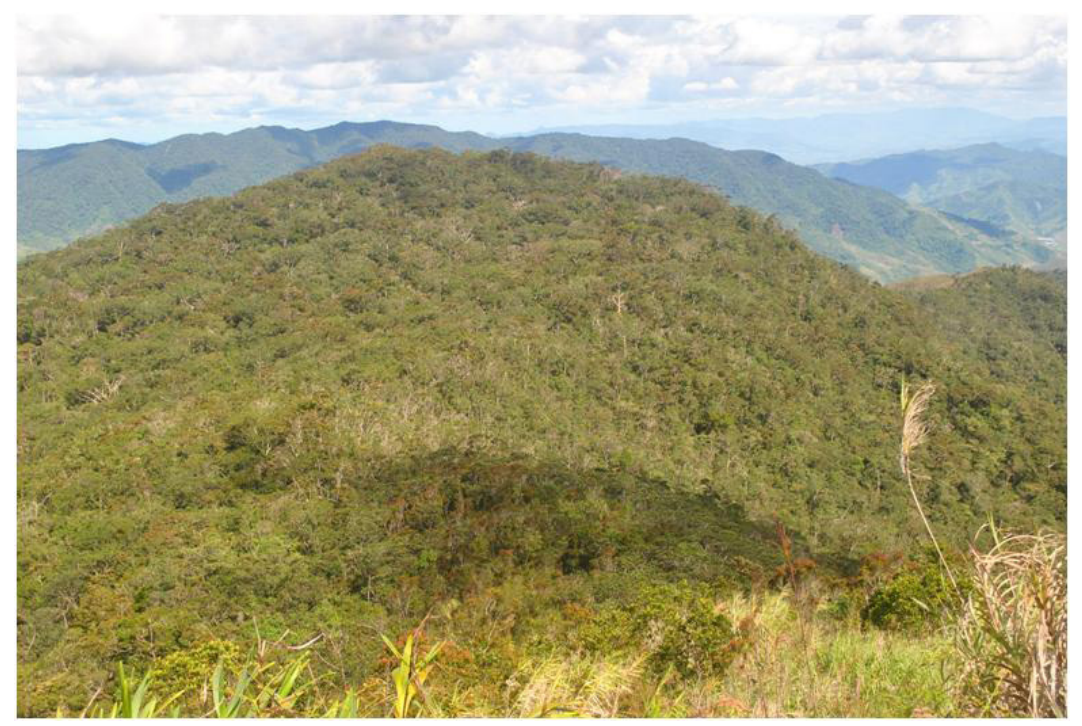

Plate 2. Mt. Kiamo Forest over Ultramafic Soils. 